Journal of Advanced College of Engineering and Management, Vol. 4, 2018

\title{
EFFECT OF FEEDING RATE ON THE REDUCTION OF TOTAL VOLATILE SOLIDS AND ORGANIC CARBON DURING COMBINED COMPOSTING AND VERMICOMPOSTING OF ELEPHANT DUNG
}

\author{
Arun Prasad Parajuli ${ }^{1}$, Iswar Man Amatya ${ }^{2}$, Ram Kumar Sharma ${ }^{3}$ \\ ${ }^{1}$ Assoc. Prof. Sagarmatha Engineering College (Tribhuvan University) \\ ${ }^{2}$ Assoc. Prof. Tribhuvan University, Institute of Engineering, Pulchwok Campus \\ ${ }^{3}$ Prof. Tribhuvan University, Institute of Engineering, Pulchwok Campus
}

\begin{abstract}
One of the methods of treatment of animal waste to conserve our nature is vermicomposting in which waste-feeding rate is one of the important parameters to be considered. This paper is concerned with studying and analyzing the effect of feeding rate on the reduction of total volatile solid and total organic carbon during vermicomposting of elephant dung.

The raw dung collected from the Central Zoo, Jawalakhel, Nepal was composted in a heap on the open ground after removal of inorganic substances by hand sorting and manually breaking of lumps. Composted dung only after two weeks was feed in the circular earthen flower pots having average diameter of $0.15 \mathrm{~m}$ and surface area of $0.017 \mathrm{~m}^{2}$ each with small holes at the bottom. The adult healthy Eiseniafetida with a stocking density of $1.6 \mathrm{~kg}$-worm $/ \mathrm{m}^{2}$ with feeding rates of $0.75,1,1.5$ and 2 $\mathrm{kg}$-feed/kg worms/day in the batch basis were used in the separate sets for vermicomposting in moisture content of 70 to $80 \%$ at normal room condition in two cycles of eight weeks after two weeks of normal composting in a room.

It was revealed from the experiment that the combined composting and vermicomposting system with feeding rate of 0.75 $\mathrm{kg}$-feed $/ \mathrm{kg}$ worms/day was more effective in reducing total volatile solids and total organic carbon content to $42.52 \%$ and $23.62 \%$ respectively after ten weeks.
\end{abstract}

Keywords: Elephant Dung; Vermicomposting; Eiseniafetida; Feeding rate; Total volatile solid; Total organic carbon

\section{Background}

Solid waste management is becoming more difficult task when the wild animals are tamed for the recreational and other purposes in the rapidly growing urbanization of the world. Animal wastes are also causing odor problems in the usual disposal techniques (Garg et al., 2004). Incineration of animal waste adds the greenhouse gases in the atmosphere so it is one of the sources of environmental pollution. The wastes from plant and animal origin provide a good source of nutrients to improve soil conditions (Padmavathiamma et al., 2007). Due to high organic content in animal waste, vermicomposting may be the one of the proper technique, which reduces its mass by reducing total volatile solids, and total organic carbon content and the final stabilized product enriched with nutrients can be used as the fertilizer. So, vermicomposting may be the appropriate option for cost effective, safe and eco-friendly disposal and utilization of animal waste.

Vermicomposting results in bioconversion of the waste streams into two useful products: the earthworm biomass and the vermicompost. The former product can further be processed into protein (earthworm meal) or high-grade horticultural compost (Garg et al., 2004). The final product (vermicompost) is also considered as an excellent product due to homogeneity, desirable aesthetics, and reduced levels of contaminants. It tends to hold more nutrients over a longer period, without adversely impacting the environment. During this process, the important plant nutrients, such as nitrogen, potassium, phosphorous and calcium present in feed material are converted into forms that are much more soluble and available to plants than those in the parent compounds (Maharjan, 2009). Vermicompost has also been reported to contain biologically active substances such as plant growth regulators (Garg et al., 2004). Involvement of earthworms for the degradation of organic wastes and 
production of vermicompost is near commercialization because loss of nitrogen from agricultural wastes and the dung is minimized when the vermicompost is the source of organic matter (Kumar and Singh, 2000). The limitation of vermicomposting is that the process must be maintained at temperatures below $35^{\circ} \mathrm{C}$. Above $35^{\circ} \mathrm{C}$, vermi cannot survive which results non killing of pathogens at acceptable range.

Elephant produces $130 \mathrm{Kg}$ of semi-digested dung in a day. Such a huge amount of dung produced by the several elephants in the zoo and park are creating problem for waste management (UNDP, 2008). In Nepalese context, the problem can be seen in Chitawan National Park, Sauraha. Elephant jungle safari in Sauraha, one of the most popular tourist hubs of Chitawan National Park is a dream for visiting tourists. There are as many as 165 private and park elephants for jungle safari and other adventures like elephant polo, which takes place once a year, with visitors coming from all around the world. Ultimately Sauraha is suffering from the unmanaged elephant dung. Each elephant produces $130 \mathrm{Kg}$ of dung a day, resulting in 165 elephants producing 21.5 metric tons of dung a day (Parajuli,2009). This is generally a nuisance and dumped in a place called 'Malkhad' to dry naturally. The dried dung is later burnt, emitting greenhouse gases like carbon dioxide into the atmosphere. Hence, the way out of management of the elephant dung in parks and zoo is considerable.

The main focus of this paper from the study is to investigate the effect of different feeding rates of on the reduction of physical parameters (total volatile solids and total organic carbon only) during vermicomposting of elephant dung. The study is limited to single species worm (Eiseniafetida) only using non-adjusted or natural $\mathrm{C} / \mathrm{N}$ ratio within the dung. The characteristics of dung is considered same, optimum stocking density $\left(1.6 \mathrm{~kg}\right.$ worms $/ \mathrm{m}^{2}$ ) and moisture content (70 to $80 \%$ ) were kept constant and the effect due to temperature variation during the study period was not considered in all cycle of experiment.

\section{Literature Review}

In Latin word, 'vermi' means the worm. When specific species of earthworms are used for the biostabilization of organic matter, it is called vermicomposting. In the other way, vermicomposting is the process by which worms are used to convert organic materials (usually wastes) into humus like materials known as vermicompost. In the process of breakdown of waste, worms feed on microorganisms, which grow on the surface of waste, and excrete particles of smaller size, which are called worm castings (Maharjan, 2009). Organic wastes can be ingested by earthworms and egested as a peat-like material termed as vermicompost (Garg et al., 2004). The passage of organic material through the earthworm gut results in physical decomposition due to the muscular grinding action of the gizzard. During vermicomposting process, the important plant nutrients such as nitrogen, potassium, phosphorous and calcium present in the feed material are converted through microbial action into forms that are much more soluble and available to plants than those in the parent substrate (Ndegwa and Thompson, 2000).

There are more than 3,000 individual species of earthworms that have been recorded throughout the world (Maharjan, 2009). The most promising earthworm species used for vermicomposting are Eiseniafetida, Eiseniaandrei, Eiseniaeugeniae and Perionyx excavates (Garg et al., 2004). On the basis of chemical analysis, the species of earthworm Eiseniafetida is superior to others in vermicomposting of municipal solid waste, in terms of loss of total organic carbon, reduction in carbon to nitrogen ratio, increase in electrical conductivity (EC) and potassium (Kaviraj and Sharma, 2003).Vermicompost worms are not subject to diseases caused by micro-organisms, but they are subject to predation by certain animals and insects (red mites are the worst) and to a disease known as "sour crop" caused by environmental conditions (Munroe, 2008). The enemies are moles, birds, centipedes, ants and mites. 
The materials needed to provide a relatively stable habitat are called bedding. Horse manure, pest moss, corn silage, hay, straw, paper, newspaper, card board, paper fiber sludge, sludge, saw dust, leaves, corn stalks, etc are the common materials that can be used as bedding (Maharjan, 2009). Eiseniafetida can survive in moisture ranges between 50 and $90 \%$ in animal wastes but grows more rapidly between 80 to $90 \%$ and $85 \%$ be the optimum (Dominguez and Edwards, 2004). Norbu (2002) suggested that the worms perform best in neutral $\mathrm{pH}$. The optimum range of $\mathrm{pH}$ is found at the range of 7.5 to 8.0 (Munroe, 2008). In vermicomposting, temperatures are kept generally kept below $35^{\circ} \mathrm{C}$ (Norbu, 2002). Eiseniafetida can survive in temperatures as low as $0^{\circ} \mathrm{C}$ to as high as $30^{\circ} \mathrm{C}$ (Maharjan, 2009). It is generally considered necessary to keep the minimum temperatures above $10^{\circ} \mathrm{C}$ (preferably $15^{\circ} \mathrm{C}$ ) for vermicomposting efficiency and minimum above $15^{\circ} \mathrm{C}$ (preferably $20^{\circ} \mathrm{C}$ ) and for productive vermiculture operations.

Earthworms are the big eaters and can consume nitrogen rich feed materials. When the material with high carbon content is used with carbon to nitrogen ratio exceeding 40, it is advisable to add nitrogen supplements like goat manure, cattle dung and pig manure to ensure effective decomposition (Norbu, 2002). Under ideal conditions, they are able to consume in excess of their body weight each day, although the general thumb rule is half of their body weight per day (Maharjan, 2009). They will eat almost anything organic (that is, of plant or animal origin), but they definitely prefer some foods to others. Worms gain maximum weight in the carbon to nitrogen ratio $(\mathrm{C} / \mathrm{N})$ range of 15 to 35 (Bhandari, 2004). Garg, et al. (2004) has successfully showed that the cow, buffalo, horse, donkey, sheep, goat and camel waste can be used as food for red worms. Earthworms eat all kinds of food and yard wastes, including coffee grounds, tea bags, vegetable and fruit waste, pulverized eggshells, grass clippings, manure, and sewage sludge (Dickerson, 2001). He suggests avoiding bones, dairy products, and meats that may attract pests, and garlic, onions, and spicy foods. Limited amounts of citrus can be added, but too much can make the compost too acidic. Overly acidic compost can be corrected by adding crushed eggshells.

Earthworms have no specialized respiratory organs, and oxygen diffuses in through body wall and carbon dioxide diffuses out (Dominguez and Edwards, 2004). If anaerobic condition is developed, they are not killed only by deficiency of oxygen but are also killed by toxic substances like ammonia created by different sets of microbes that bloom under these conditions (Maharjan, 2009). They operate best when ventilation is good and the material they are living in is relatively porous and well aerated. The one of the major benefits of vermicomposting is that the worms aerate their bedding by their own movement through it and turn of the material may not be needed.

Stocking density means the total amount of the worm required (by weight) per unit surface area of the vermi bed. The feeding rate represents the amount of feed (by weight) required for a unit weight of worms in a day. For vermicomposting using Eiseniafetida, an optimal worm stocking density is $1.6 \mathrm{~kg}$ worms $/ \mathrm{m}^{2}$ and feeding rates of 0.75 to $1.5 \mathrm{~kg}$-feed/kg worms/day is suitable (Ndegwa et al., 1999). He has shown that a stocking density of $1.6 \mathrm{~kg}$ worms $/ \mathrm{m}^{2}$ and a feeding rate of $1.25 \mathrm{~kg}$-feed $/ \mathrm{kg}$ worms/day resulted in the highest bioconversion of substrate into earthworm biomass and the best vermicompost was obtained at the same stocking density and a feeding rate of $0.75 \mathrm{~kg}$-feed $/ \mathrm{kg}$ worms/day.

Earthworms are very sensitive to the salt content. The preferred level of salt is less than $0.5 \%$ (Karkee, 2005 and Maharjan, 2009). The pre-composting of wastes before using it in vermicomposting can reduce the problem due to salt (Maharjan, 2009). Various animal excreta were tested in the past as the feed material for the different species of earthworm. Worms could not survive in the fresh animal waste (Garg, et al., 2004). He has studied about the survival, growth and reproduction of Eiseniafetida in cow, buffalo, horse, donkey, sheep, goat, and camel waste. The waste

jacem, Vol.4, 2018 Effect of Feeding rate on the Reduction of Total Volatile Solids and Organic Carbon During Combined Composting and Vermicomposting of Elephant dung 
was feed only after two weeks so that the volatile toxic gases were eliminated. UNDP (2008) reported about the truth of survival, growth and reproduction of Eiseniafetida in elephant dung in Chitwan National Park of Nepal.

The degree of composting or maturity of compost can be estimated by measuring the final drop in temperature, degree of self-heating capacity, amount of decomposable and resistant organic matter in the composted material, rise in the redox potential, oxygen uptake, growth of the fungus chaetomiumgracills, and the starch iodine test (Tchobanoglous et al., 1993). The determination of maturity of compost is really a difficult task of complexities of processes and lack of comprehension or appreciation of many of its aspects (Maharjan, 2009). Temperature decline at the end of batch composting is the one of the approaches to measure the degree of compost stabilization are as follows (K. C., 2000).

\section{Methodology}

The study was carried out in two cycles with a time period of 10 weeks each in a room at Koteshwor, Kathmandu, Nepal. The first cycle (cycle I) was conducted from March to May and the second cycle (cycle II) from August to October, 2009. In all the cycles, Eiseniafetida with worm stocking density of $1.6 \mathrm{~kg}$ worms $/ \mathrm{m}^{2}$ was used for vermicomposting as adopted by Ndegwa et al (1999). The cycle I was carried out with a composting and two sets of vermicomposting with the feeding rate of $0.75 \mathrm{~kg}-$ feed/kg worms/day and $1 \mathrm{~kg}$-feed/kg worms/day respectively in batch basis. Similarly, the cycle II was carried out with a composting and two sets of vermicomposting with the feeding rate of $1.5 \mathrm{~kg}-$ feed/kg worms/day and $2 \mathrm{~kg}$-feed/kg worms/day respectively in batch basis. In each cycle, about 300 kgs of the Elephant dung was first collected manually in the zoo of Jawalakhel, Lalitpur, Nepal and transported to the research place at Koteshwor, Kathmandu, Nepal. The inorganic substances were removed by hand sorting and the lumps were broken manually to make the dung ready for composting.

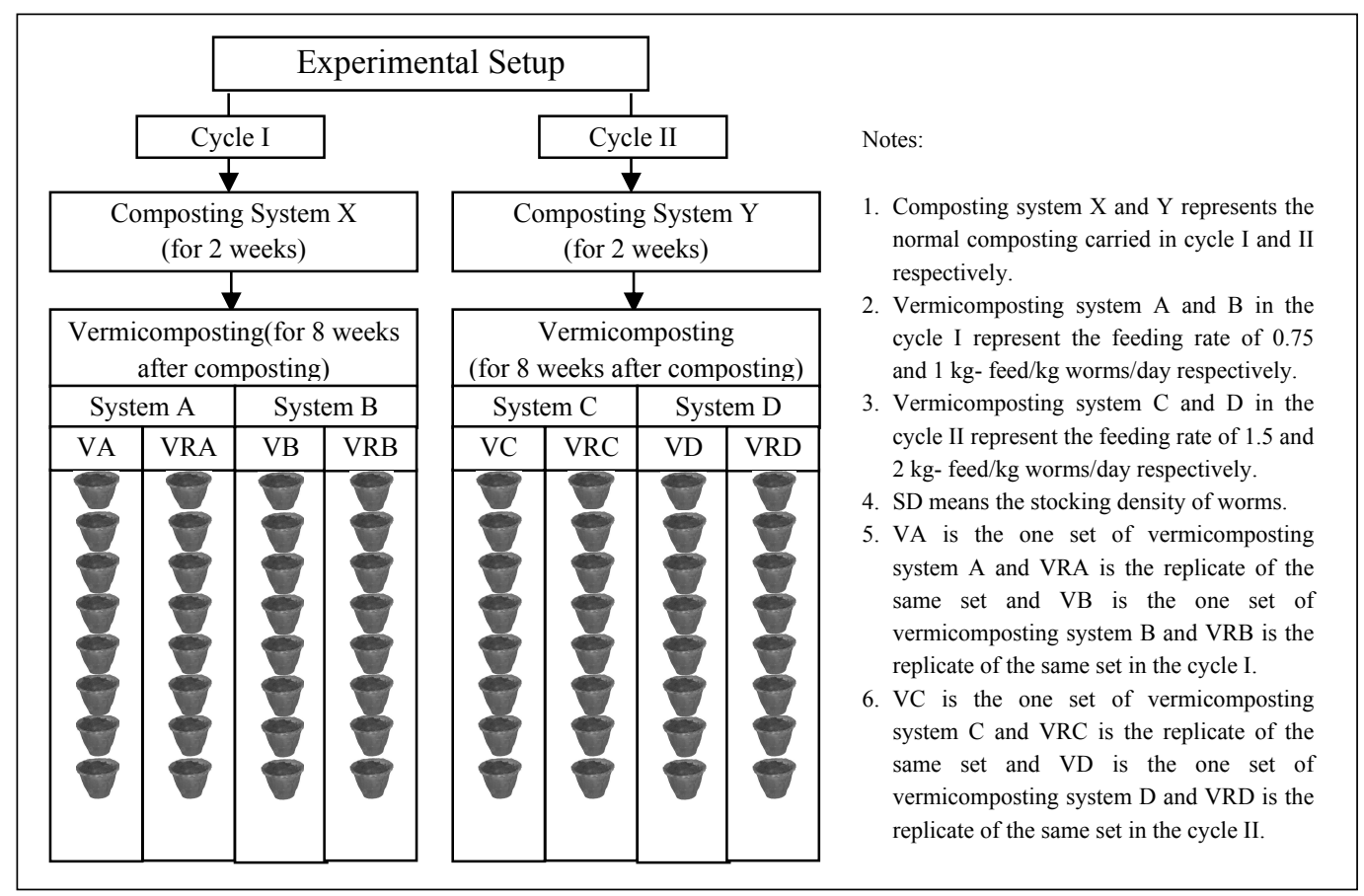

Fig. 1: Conceptual diagram of experimental setup 
Due to easy availability and successful results in the earlier studies with in the local environment at Kathmandu, Eiseniafetida is used for this study. The worms were collected from Kathmandu Metropolitan City. In both cycles, the worms were acclimatized in the dung with normal composting in a heap for two weeks to avoid mortality of worm as recommended by Garg et al., (2004) before launching in vermicomposting experiment. The conceptual diagram of experimental setup is presented in the Figure 1.

A vermicomposting practice on elephant dung in Sauraha, Chitawan shows that 45 days are required to get vermicompost (UNDP, 2008). The eight-week experimental duration was chosen to coincide with the approximate generation time of Eiseniafetida as done by Ndegwa et al (1999). So, eight sets of vermicompost bins were selected in the study and each set was considered only at once in a week for observations.

For composting, the open yard was selected for making the composting heap. The heap was covered with straw at normal days and covered with plastic at the time of rain. The compost heap was turned over manually once a day at evening time for aeration. The moisture content was daily monitored with eye judgment and maintained at the range of 70 to $80 \%$ by spraying adequate quantity of water if necessary.

For vermicomposting, thirty-two numbers of the circular earthen flower pots each with small holes at the bottom and average diameter of $0.15 \mathrm{~m}$ (surface area of $0.017 \mathrm{~m}^{2}$ ) were taken in both cycle I and II. The adult healthy worms with a stocking density of $1.6 \mathrm{~kg}$-worm $/ \mathrm{m}^{2}$ were taken for vermicomposting in both cycles. It means $28.27 \mathrm{~g}$ worms per pot which was satisfied by 116 numbers of worm in the experiment of each cycle. Mortality of all worms within 24 hours was observed in the mortality test conducted with 10 worms on the pot filled with fresh dung before test in cycle I.

In the cycle I, first sixteen pots were arranged for a feeding rate of $0.75 \mathrm{~kg}$-feed $/ \mathrm{kg}$ worms $/$ day $(1.19$ $\mathrm{kg}$ dung) and remaining sixteen were arranged for a feeding rate of $1.0 \mathrm{~kg}$-feed $/ \mathrm{kg}$ worms $/ \mathrm{day}(1.58$ $\mathrm{kg}$ dung) in batch basis for eight weeks (ten weeks from the date of composting). Among each sets of sixteen pots, eight pots were the replicate of remaining eight pots and were made to check consistency. One pair of each set was observed in a week and then discarded. Same disturbed pair was not used for further observations to avoid the misleading result due to the disturbance to the worm after counting and the deficiency of dung material after sample withdrawal.

In the cycle II, first sixteen pots were arranged for a feeding rate of $1.5 \mathrm{~kg}$-feed $/ \mathrm{kg}$ worms $/$ day $(2.37$ $\mathrm{kg}$ dung) and remaining sixteen were arranged for a feeding rate of $2.0 \mathrm{~kg}$-feed $/ \mathrm{kg}$ worms $/$ day $(3.17$ $\mathrm{kg}$ dung) in batch basis for eight weeks (ten weeks from the date of composting) and proceeded as in the cycle I.

Table 1: Parameters measured during study

\begin{tabular}{|c|c|c|c|c|c|}
\hline S. No. & Parameters & Method used & Reference & $\begin{array}{c}\text { Frequency } \\
\text { of test }\end{array}$ & Remarks \\
\hline 1 & $\begin{array}{l}\text { Total volatile } \\
\text { solids }\end{array}$ & Ignition at $550^{\circ} \mathrm{C}$ & APHA (1989) & & $\begin{array}{c}\text { Pulchwok Campus, } \\
\text { Nepal Lab }\end{array}$ \\
\hline 2 & $\begin{array}{c}\text { Total organic } \\
\text { carbon }\end{array}$ & $\begin{array}{l}\text { Empirical formula } \\
\text { by Gottas (1971) }\end{array}$ & Bhandari (2004) & Weekly & - \\
\hline \multicolumn{6}{|c|}{$\begin{array}{l}\text { Empirical formula by Gottas (1971) as adopted by Bhandari (2004), } \\
\% \text { TOC }=\frac{\% \mathrm{TVS}}{1.8} \\
\text { Where, \% TOC and \%TVS are total organic carbon and total volatile solids respectively in percentages. }\end{array}$} \\
\hline
\end{tabular}

The moisture content was daily monitored with eye judgment and maintained at 70 to $80 \%$ by spraying adequate quantity of water if necessary as adopted by Nedgwa et al (1999) as well as 
Dominguez and Edwards (1996). All the pots were arranged in a room and covered with wire mesh so that the air can pass with ease which is essential for the worms to survive and to protect from rats, scavengers. Dark environment favorable to the earthworms inside the room were maintained. The experiment was conducted at the room temperature. The lab tests of required parameters and the frequency of observations as well as sampling for chemical analysis during the study and the methods used are presented in the Table 1.

\section{Result and Discussion}

Mortality of $100 \%$ worms within 24 hours was observed when they were kept on the pot filled with fresh dung due to evolution of volatile toxic gases in the mortality test conducted before the cycle I. So, vermicomposting was carried out only after two weeks of normal composting in a heap. No mortality of the worms was observed in all set of vermicomposting after two weeks of normal composting in the all cycles. In each cycles, the effect of feeding rate during combined composting and vermicomposting on total volatile solids and total organic carbon were observed and analyzed.

\subsection{Variations in Total Volatile Solids}

The variation in the total volatile solids in different systems in both cycles has been presented in the Figure 2.

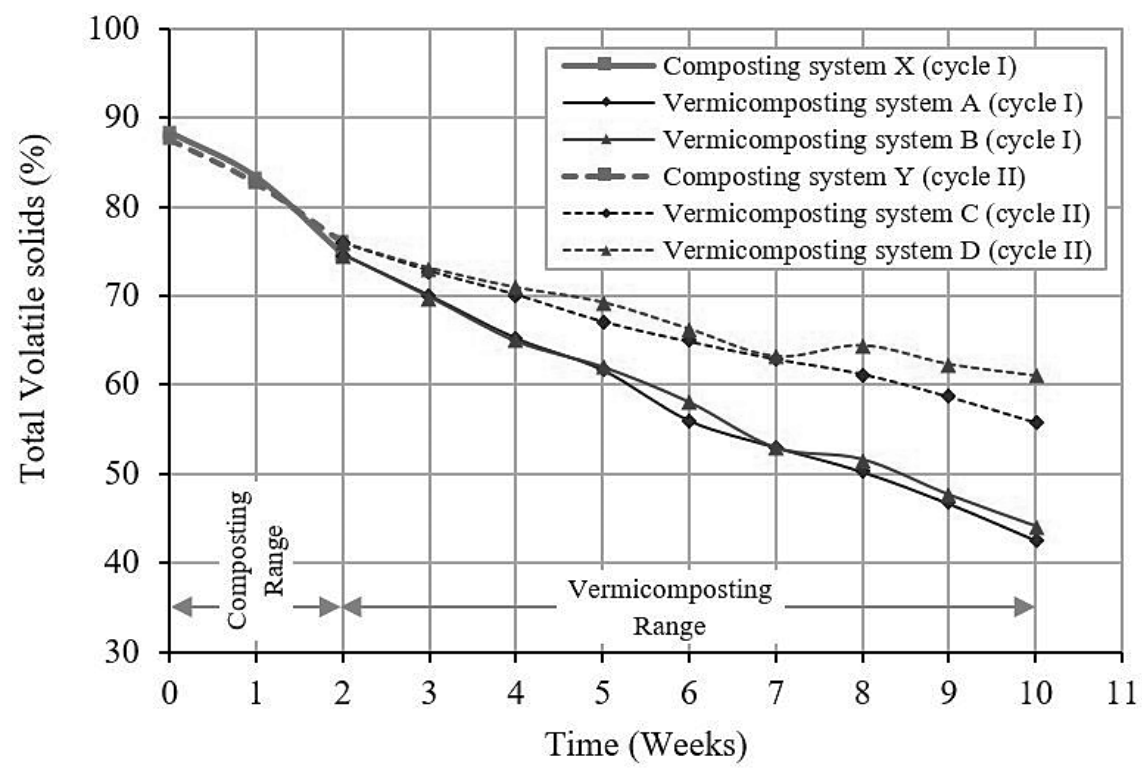

Fig. 2: Variations of volatile solids in the different system

In Cycle I, the raw dung containing the volatile solids of $83.33 \%$ was reduced to $74.63 \%$ after 2 weeks by normal composting system $\mathrm{X}$ and it is further reduced to $42.52 \%$ and $44.12 \%$ by vermicomposting system $\mathrm{A}$ and $\mathrm{B}$ respectively at $10^{\text {th }}$ week of combined composting and vermicomposting (after 8 weeks of vermicomposting).In cycle II, the raw dung containing the volatile solids of $87.50 \%$ was reduced to $75.98 \%$ after 2 weeks by normal composting system $\mathrm{Y}$ and it is further reduced to $55.77 \%$ and $60.99 \%$ by vermicomposting system C and D respectively at $10^{\text {th }}$ week of combined composting and vermicomposting (after 8 weeks of vermicomposting).

The volatile solid content of the waste significantly decreased in all the systems of combined composting and vermicomposting in both cycles. The reduction of volatile solids in composting is due

jacem, Vol.4, 2018 Effect of Feeding Rate on the Reduction of Total Volatile Solids and Organic Carbon during Combined Composting and Vermicomposting of Elephant Dung 
to the utilization by microorganisms and for respiration and cell growth whereas in vermicomposting reduction occurs additionally by the worm activity and its mass growth. The volatile solids representing the organic matter were in decreasing trend throughout the experiment period. The reduction is an indication of stabilization of the compost (Maharjan, 2009).

Among all, the combined composting and vermicomposting system, system A is more effective in total volatile solids reduction among all systems and it may be due to the lowest feeding rates.

\subsection{Variations in Total Organic Carbon}

Total organic carbon was derived from the volatile solid data as per empirical formula by Gottas (1971) as stated by Bhandari (2004). It can be related by dividing total volatile solids by 1.8. So, the change in the total organic carbon in the different systems of both cycles followed the similar trend as in the total volatile solids and has been presented in the Figure 3.

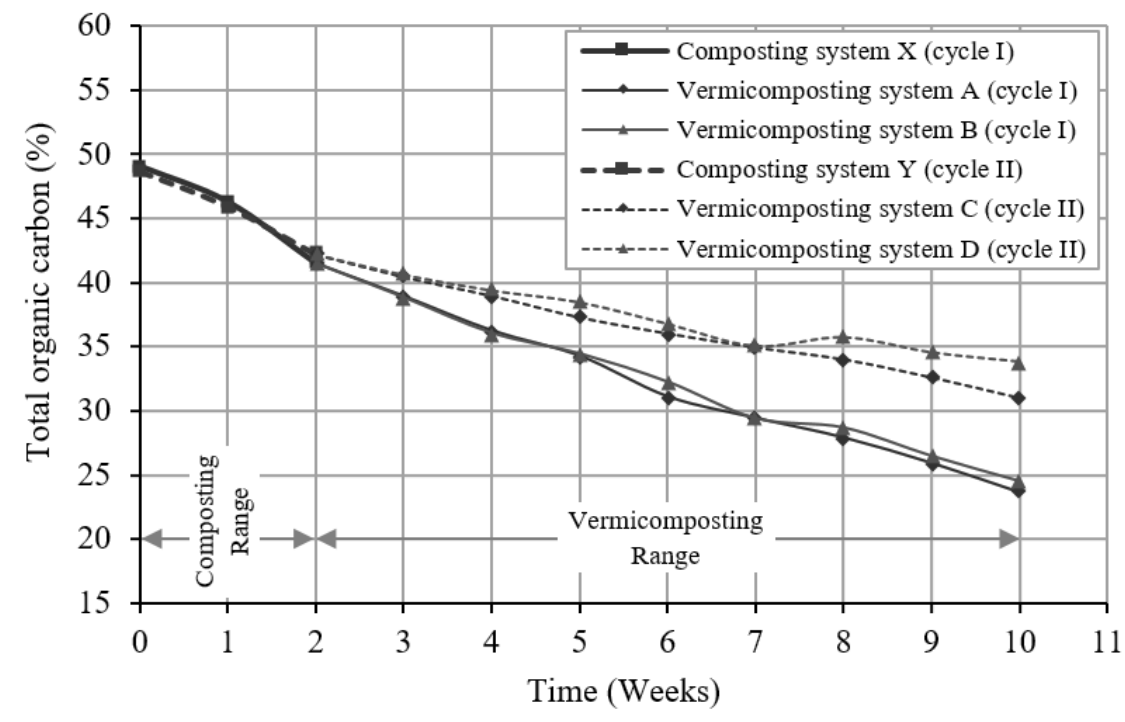

Fig 3: Variations of total organic carbon in the different systems

In Cycle I, the raw dung containing the organic carbon of $49.07 \%$ was reduced to $41.46 \%$ after 2 weeks by normal composting system $\mathrm{X}$ and it is further reduced to $23.62 \%$ and $24.51 \%$ by vermicomposting system $\mathrm{A}$ and $\mathrm{B}$ respectively at $10^{\text {th }}$ week of combined composting and vermicomposting (after 8 weeks of vermicomposting). In cycle II, the raw dung containing the organic carbonof $48.61 \%$ was reduced to $42.21 \%$ after 2 weeks by normal composting system $\mathrm{Y}$ and it is further reduced to $30.98 \%$ and $33.88 \%$ by vermicomposting system $\mathrm{C}$ and $\mathrm{D}$ respectively at $10^{\text {th }}$ week of combined composting and vermicomposting (after 8 weeks of vermicomposting).

The reduction in total carbon content is due to the combustion of carbon substances during the respiration and therefore represents the microbial activity in the compost (Maharjan, 2009). The reduction of more total organic carbon in vermicomposting system A shows a greater mineralization rate in that vermicompost system.

Among all, the combined composting and vermicomposting system A is more effective in total organic carbon reduction among all systems and it may be due to the lowest feeding rates. 


\section{Conclusion and Recommendation}

From the experiment, it was concluded that the direct vermicomposting in raw elephant dung is $100 \%$ fatal for Eiseniafetida but combined composting and vermicomposting could be carried out successfully in the elephant dung. Based on the results obtained from the experiment and analysis of the results, the following conclusions were drawn;

1. The total volatile solids of the waste were in decreasing trend in all combined composting and vermicomposting systems. The volatile solid content at the $10^{\text {th }}$ week were $42.52 \%, 44.12 \%$, $55.77 \%$ and $60.99 \%$ in combined composting and vermicomposting systems with feeding rates of $0.75,1,1.5$ and $2 \mathrm{~kg}$-feed $/ \mathrm{kg}$ worms/day respectively. The combined composting and vermicomposting system with a lower feeding rate as $0.75 \mathrm{~kg}$-feed $/ \mathrm{kg}$ worms $/$ day was more effective in the reduction of total volatile solids among all vermicomposting systems.

2. The values of total organic carbon showed a similar declining trend as in the volatile solids with time indicating the stabilization process of the waste. The values of total organic carbon in the ${ }^{10}$ th week were $23.62 \%, 24.51 \%, 30.98 \%$ and $33.88 \%$ in combined composting and vermicomposting systems with feeding rates of $0.75,1,1.5$ and $2 \mathrm{~kg}$-feed/ $/ \mathrm{kg}$ worms/day respectively. The combined composting and vermicomposting system with a lower feeding rate as $0.75 \mathrm{~kg}$-feed/ $\mathrm{kg}$ worms/day was more effective in the reduction of total organic carbon among all vermicomposting systems.

Comparing all results, it can be concluded that the direct vermicomposting in raw elephant dung is not possible because of $100 \%$ mortality of Eiseniafetida but combined composting and vermicomposting system is more effective in reducing total volatile solids and total carbon content. So, it is recommended to the Chitawan National Park, Sauraha and Central Zoo, Jawalakhel for choosing the combined composting and vermicomposting of elephant dung with a stocking density of worm $1.6 \mathrm{~kg}$ worms $/ \mathrm{m}^{2}$ and a feeding rate of $0.75 \mathrm{~kg}$-feed $/ \mathrm{kg}$ worms $/$ day for vermicomposting to reduce total volatile solid and organic carbon of elephant dung in the final product.

It is recommended for further study using the worm species other than Eiseniafetida, varying $\mathrm{C} / \mathrm{N}$ ratio, temperature controlled condition etc. It also recommended to study on the appearance of the pathogens on vermicompost. 


\section{References}

1. APHA, (1989), "Standard Methods for the Examination of Water and Wastewater". American Public Health Association, New York.

2. Bhandari, H. S., (2004), "Survival Growth and Reproduction of EiseniaFetida During degradation of Dried Human Feces". MSc. Thesis No. 058/MSE/302, IOE, Pulchowk-Nepal.

3. Dickerson, G.W., (2001), “Vermicomposting”. Guide H-164, New Mexico State University

4. Dominguez, J. and Edwards, C.A., (1996), "Effects of Stocking Rate and Moisture Content in the Growth and Maturation of Eisenia Andrei (Oligochaeta) in Pig Manure". Elsevier Science Ltd., Vol. 29, No. 3/4

5. Dominguez, J. and Edwards, C.A., (2004), "Vermicomposting Organic Wastes: A Review". Ohio State University, Columbus, Ohio, USA

6. Garg, V.K., Chand, S., Chhillar, A. and Yadav, A., (2004), "Growth and Reproduction of EiseniaFoetida in Various Animal Wastes During Vermicomposting". Guru Jambheshwar University, Hisar 125001, India.

7. K. C., B.B., (2000), "Use of Weed Plant (Lantana Camara) Material as a Bulking Agent in Municipal Organic Waste Composting". MSc. Thesis No. 055/EE/Roll No. 202, IOE, Pulchowk-Nepal.

8. Karkee, S., (2005), "Decomposition of Fresh Feces by Vermicomposting under SemiContinuous Loading”. MSc. Thesis No. 060/MSE/314, IOE, Pulchowk-Nepal.

9. Kaviraj and Sharma, S., (2003) "Municipal Solid Waste Management Through Vermicomposting Employing Exotic and Local Species of Earthworms". Bioresource Technology, 90: 169-173

10. Kumar, V. and Singh, K.P., (2000) "Enriching Vermicompost by Nitrogen Fixing and Phosphate Solubilizing Bacteria". Bioresource Technology, 76: 173-175

11. Maharjan, G.R., (2009), "Treatment of municipal Solid Waste by Combining Composting and Vermi Composting Using EiseniaFetida". MSc. Thesis No. 062/MSE/304/141, IOE, Pulchowk-Nepal.

12. Munroe, G., (2008), "Manual of On-farm Vermicomposting and Vermiculture". Organic Agriculture Centre of Canada, Canada

13. Ndegwa, P.M. and Thompson, S.A., (2000), "Integrating Composting and Vermicomposting in the Treatment and Bioconversion of Biosolids". Bioresource Technology,76: 107-112

14. Ndegwa, P.M., Thompson, S.A. and Das, K.C., (1999), "Effects of Stocking Density and Feeding Rate on Vermicomposting of Biosolids". Bioresource Technology, 71: 5-12

15. Norbu, T., (2002), "Pretreatment of Municipal Solid Waste by Windrow Composting and Vermicomposting", MSc. Thesis, Asian Institute of Technology, Bankok, Thailand.

16. Padmavathiamma, P.K., Li, L.Y. and Kumari, U.R., (2007), "An Experimental Study of Vermi-biowaste Composting for Agriculture Soil Improvement", University of British Columbia, Vancouver, Canada

17. Parajuli A.P., (2009), "Combined Composting and Vermicomposting of Elephant Dung”. MSc. Thesis No. 062/MSE/r/301/149, IOE, Pulchowk-Nepal.

18. Tchobanoglous, G., Theisen, H. and Vigil, S., (1993), "Integrated Solid Waste Management, Engineering Principles and Management Issues". McGraw-Hill, Int. Singapore.

19. UNDP (2008), “UNDP Nepal Newsletter”. Issue 19, July 2008

jacem, Vol.4, 2018 Effect of Feeding rate on the Reduction of Total Volatile Solids and Organic Carbon During Combined Composting and Vermicomposting of Elephant dung 